\title{
Retrofitting Javanese Traditional Games as Indonesia Culture Identity: Providing English Vocabulary
}

\author{
${ }^{1}$ Suhono. ${ }^{2}$ Yeasy Agustina Sari. ${ }^{3}$ Wiwied Pratiwi \\ ${ }^{1}$ Institut Agama Islam Ma'arif NU Metro Lampung \\ ${ }^{2}$ Institut Agama Islam Negeri Metro Lampung \\ ${ }^{1}$ suhono120708@gmail.com ${ }^{2}$ yeasy120708@gmail.com
}

\begin{abstract}
Abstrak
Permainan tradisional Jawa merupakan salah satu budaya yang diwariskan dari masyarakat turun temurun yang sangat bermanfaat bagi masyarakat, khususnya untuk mendidik anak-anak. Sayangnya, dampak game modern di era modern dari negara lain telah meruntuhkan posisi permainan lokal. Hal itu nampaknya memberi dampak negatif bagi anak-anak saat ini. Mereka cenderung fokus pada game baru di google playstore tanpa memahami nilai edukatif dari game itu. Akibatnya anak-anak meninggalkan permainan tradisional Jawa dan meninggalkan permainan edukatif. Peneliti bertujuan untuk memodifikasi permainan tradisional Jawa dalam menyajikan kosa kata bahasa Inggris bagi anak-anak untuk memotivasi mereka dalam belajar bahasa Inggris. Untuk mengatasi masalah tersebut, peneliti mengadaptasi model Kemp and Yalden dari rancangan program instruksional untuk perkuatan permainan Tradisional Jawa. Hasilnya menunjukkan bahwa permainan Tradisional Jawa: Pembelajaran Alfabet adalah hasil yang disempurnakan dari permainan Sobyong, Pembelajaran Hari adalah hasil yang direkonstruksi dari permainan Engklek, Pembelajaran Warna adalah hasil yang disempurnakan dari permainan "Jamuran", dan Pembelajaran bagian - bagian tubuh manusia, adalah hasil yang diperbaiki dari "Oyak- Oyakan". Modifikasi permainan ini bisa dinikmati dalam proses belajar kosa kata bahasa inggris.
\end{abstract}

Kata Kunci : Retrofitting Javanese Traditional Games, Sobyong, Jamuran, Engklek, Oyak-oyakan, English Vocabulary

\begin{abstract}
A traditional Javanese game was one of the cultures inherited of hereditary society which has great value to society, specifically to educate the children. Unfortunately, the impact a lot of modern games in modern era from other countries has demolished the position of local games. It seem gave negative impact for children
\end{abstract}


today. They tend to focus on new game (download new game continuously) in Google play store without understanding educative value of it's game. Consequently the children abandon traditional Javanese game and leave educative game. The researcher aimed to retrofit traditional Javanese games to provide English vocabulary for children in order to motivate them in Learning English. To solve the problem the researcher adapted Kemp and Yalden model of instructional program design to retrofitting Javanese traditional game. The result showed that Javanese traditional games: Learning alphabet was the result retrofitted from Sobyong game, Learning days was the result retrofitted from Engklek game, Learning Colors was the result retrofitted from "Jamuran" game, and Learning part of body was the result retrofitted from "Oyak- Oyakan". These modification games could be enjoyed in English vocabulary learning process.

Key words: Retrofitting Javanese Traditional Games, Sobyong, Jamuran, Engklek, Oyak-oyakan, English Vocabulary,

\section{INTRODUCTION}

Indonesia culture was very complex which many kinds of traditional culture, for instance traditional games. More than fifty games which was played by people around region of Indonesia and it was as Indonesia culture identity as tools to stimulate more effective learning and to engage learning environment. Sobyong, Jamuran, oyok-oyokan, engkleng, and cublak - cublak suweng were example of children's traditional Javanese games. Because of the benefits aspect of tendered by traditional games, in this globalization era, more children seem to neglect the games. Interesting modern games sooner or later changes the position of traditional games as original in each society and culture of Indonesia. So that the lack of social interaction and actual hands-on activities involving tactile and kinesthetic training is the most significant loss in children's development. Furthermore, the interesting game of Google play store on smart phone put aside the existence of traditional games as the original local culture. It would be result potential problems for the traditional games it self. 
English as Foreign Language, specially learning vocabulary for children, need more effective way to be understood as the basic of Learning English. Learning English sensed hard and tough to be learned. to ensure that English learning become attractive, a teacher should be able to choose the appropriate teaching learning materials in order to arise students' interest into account. Playing games is one of exciting class activity to provide students interest. Lee (1979) suggested that games ought to be the heart of teaching foreign languages. A game should not be regarded as a marginal activity filling in odd moments when the teacher and class have nothing to do. Language game will facilitate what children need. So far, designing game has been studied by foreign language which involves the learners on the different background country, for instance the researchers Ioannidi, et.al. from Greece who studied designing games for children with development disabilities in ambient intelligence environments. It presented the design of interactive games for children based on OT expertise and practice. The result shows that That games are able to adapt accordingly and provide important information regarding the abilities and skills of a child and the inferred development progress over time. This was achieved by employing OT knowledge during design process and by exploiting existing technological components such as an interactive table for preschool children. The second was the researchers Malinverni, et.al. From Spain studied an inclusive design approach for developing video games for children with Autism Spectrum disorder. The goal of this approach is to design a game that is effective in terms of therapeutic and that is enjoyable and engaging for children. The result show that with 10 children with ASD (4-6 years old) suggest that children enjoyed the game. Previous study above were very different from this present study since focus on retrofit traditional game as Indonesian culture identity, furthermore this present study used design Kemp and Yalden model. In the scope of designing game, especially the researchers in Indonesia, studying it which related to retrofit the game are rarely done by the researchers. Hence, the aim of this research was how Javanese traditional games were retrofitted to provide a set of English vocabulary games for children age 7 until 11 . So that the children were fun to learn English when they practice English Vocabulary. 
The choose traditional games will be adapted and changed into language games, so that the children practice easily to get new words through games. The retrofitted games were intended to be the supplement of the existing material. Some children in Solo may still know or instead they do not know about the traditional games at all. As traditional games used in this study are from Yogyakarta, therefore cultural kept in the games are relevant to the children in those regions. This study is not going to investigate those traditional games, but to retrofit the games so that they can be used to learn English vocabulary. As a repercussion, the researchers needs to think about the suitable technique to accommodate the vocabulary learning and children's traditional games in one pack. Therefore, a creative design of instructional material bringing the issues above is need to aid the teacher in learning process.

\section{THEORETICAL REVIEW}

\section{Javanese Traditional Games}

Javanese traditional games are part of culture identity of Indonesian culture. It is one of the product of Javanese society. Their presence should not be neglected in this modern era since they provide cultural value which is important as identity of a nation. Traditional games contain the educative values which are important for the children's development. The educative values kept in the games are universal and the children can absorb them by playing the games. Hence, traditional games are significant to be actualized in this modern era especially when the relationship in this era tends to be individualistic and impersonal.

Dharmamulya divided Javanese traditional games into three patterns, for instance playing with songs or dialogues, playing with thinking, playing with physical agility. The example of playing with songs or dialogues is cublak cublak suwerng, Jamuran, Dhoktri, Dhingklik Oglak - aglik, Koko. The example of playing with thinking is bas -basan Sepur, Dhakon, Macanan, Mul - Mulan, and the exmple of playing with physical agility is angklek, Benthik, Jeg - jegan, Dhul - Dhulan. From this example above the Javanese traditional games were very complex aspect to 
grow the children's thinking and physical condition. Because not only focus on growing thinking children, but also on kinesthetic, visual, and verbal aspect. Moreover Ariani sugessted the traditional games have the moral value to the children, namely:

- democracy values

Before starting the game, the children need have a simple discussion to decide what game they want to play, area to play, rule of the game

- education values

Children traditional games are appropriate to convey education both physically and spiritually. Children traditional games teach social, discipline, ethics, honesty, independence, and confidence.

- personality values

In playing traditional games, a child interacts with his friends with various characteristics. The games offers challange in which child need to survive, struggle, ande help others. Therefore child's personality is trained to grow good attitude and wisdom when he is adult

- courage values

courage is needed to take a decision about what strategy should be used to survive or to oppose.

- health values

Most of the activity used in children traditional games involve body movement such as running, jumping, standing, catching, and holding. It will release tense, emotion, and frustration that children have

- unity values

The characteristic of Javanese society is to emphasize the harmony of the social life. The society interest must be given precedence rather than individual interest.

- moral values

In playing traditional game, each child in one team should protect each other, help each other, and try not to hurt others in order to survive and achieve 
victory. In Playing, children need to control their emotions if there is something not pleasing

\section{Games For Learning Vocabulary}

Children cannot be separated from play activities. In this regard, children are driven to activity and to learning by play rather than any work motive or other sophisticated motivate that drives adults. Not to include games in English instruction is like to with hold children from essential tools that assist them to understand the world. The close relation between children and playing activity indirectly leads a child to his way of life and shape his personal characters. It implies that a child whose need of playing is not well fulfilled must not develop perfectly. Campbell added games involve students in imaginative and chalenging situation that increase factual knowledge, making decission, and interpersonal skills. Most of students learn eagerly and enthusiastically through games. In reference to Budianto His research describes some benefits of using game in teaching learning activities:

- Students' longer retention (Providing opportunity for students to experience something)

- The effectiveness as shared by group work (the students will have opportunity to interact with one another friends freely)

- Minimum role of teacher (the students will be active meanwhile the teacher only monitor them during they are playing the game)

- Large among of skill practices (games also allow students to learn about competition, cooperation, and the social system with others)

- Development of creativity (learning to understand the situation, to identify what to do think critically over any possible situation, to take decision)

\section{Constructing Games in Language Teaching}

Bell described some steeps to construct games for learning:

- Consider the objective

(Instructional objective of games should be clarified first in order to make the 
activities successful. The objective of the game will guide the designers to construct the game so that the element of learning is still $\mathrm{s}$ the main objective of the game not merely playing the game.

- Determine the grade level

- Specify the numbers players

- Determine the format

The format of the game depends on te objective of the game. The formal can be board game, card game, and role-play. The board game format is in which a graphic representation of the process under study, allowing players to keep track of their opponents.

- Design and gather the materials

The designer select the material for the actual game construction. The material should be attractive, functional, and made from durable materials.

- Describe the players' role

There are three different types of roles in a game

- Individual roles

- Maintained roles

- Task roles

- Clarify the procedure and time

- Trial run

To know what the problem arise, thus the game designer needs to try out the constructed game into a small group of children. During the action, the designer can observe and write down the problem that occur.

- Evaluation

For Evaluation of the constructed game, the game designer can use these questions: Did the students achieve the objective of the game? What objective were met by playing the game? What difficulties were experienced?

\section{Kemp's and Yalden's Design Model}

Kemp suggested that his method can be applied on educational levels, for 
instance elementary, secondary, or college. The designers are supposed to seek out information about the objectives of the instructional design, the activities and resources and the evaluation of the instructional design. Kemp offers eight elements to design the program development namely:

- Goals, Topic, and General Purpose: consider goals, list topics, and state the general purpose for each topic.

- Learner's characteristics: numerate the important characteristic of the learner for whom the instructional to be designed

- Learning objectives: specify the learning objective to be achieved in term of measurable students behavioral outcomes

- Subject content: design the learning materials that support the attainment for each specific instructional objective

- Pre-assessment: develop pre- test to determine the students' background and present level of knowledge.

- Teaching learning activities and resources: select teaching or learning activities and instructional resources that can be applied to achieve the specific instructional objective appropriate for accomplish each objective.

- Support services: coordinate such support service as budget, personal, facilities, ad schedule to carry out the instructional

- Evaluation: evaluate students' learning in term of their accomplishment of objectives.

Kemp reminds that this process of developing program is flexible since among the eight element are independent. The designer therefore can start from whiever element and should treat most of the eight elements. Revisions of elements are necessary through evaluation of students' accomplishment of objectives.

Furthermore Yalden (1987) presents the stages to design a communicative syllabus. The model consist of seven stages, namely:

- Need Survey (gather information about the learners, such as personal needs, motivation)

- Description of the purpose 
- Choice of a syllabus type

- Production of proto-syllabus

- Production of pedagogical syllabus

- The development and implementation of classroom procedures

- Evaluation

\section{RESERCH METHOD}

The researchers used two research methods: library research and survey research. The library research was conducted, to appropriate theories of designing instructional materials, especially related to teaching and learning vocabularies. The survey conducted to children's interests and English teachers' opinions, and survey on English teacher evaluation about the game. The subject of this research were the children at the age 6 to 11 of Primagama Course at Solo City. The researcher used interview and questionnaire as research instrument of this present study. Furthermore, the researchers used Kemp and Yalden model of instructional program design to retrofitting Javanese traditional game.

\section{FINDING AND DISCUSSION}

The aim of this study investigated how Javanese traditional games were retrofitted to provide a set of English vocabulary games for children age 7 until 11. The researchers adopted and combined two instructional models, Kemp and Yalden Theory. After obtaining the data, the researchers distributed the questionnaires to some respondents and tried out the game to a group of children. It can be proven from evaluation survey result in which the grand mean: 3.13, the grand modus: 2, and the grand median: 2. The researchers concluded that English researchers accept the game in this study were appropriate to be used as alternative activities in teaching English vocabulary of children age 6- 11. The result show that the children were happy and enthusiastic knowing the game and they really enjoyed the activities provided in each game. Basically, they had known with those games.

There were fours traditional games which were retrofitted, Sobyong, Jamuran, 
Engkleng, and Oyok-oyokan. Some procedure were added, maintained, or even cut in order to provide the games that served the students to achieve the learning objective. Part of the procedures of the game which were modified are presented:

Table 1. Part of Traditional Games Which are Modified

\begin{tabular}{|c|c|c|c|c|}
\hline No & Games & $\begin{array}{l}\text { Part which were } \\
\text { retrofitted }\end{array}$ & $\begin{array}{l}\text { Before being } \\
\text { retrofitted }\end{array}$ & $\begin{array}{l}\text { After being } \\
\text { modified }\end{array}$ \\
\hline \multirow[t]{3}{*}{1.} & Sobyong & $\begin{array}{l}\text { The name of the } \\
\text { game: }\end{array}$ & Sobyong & "Magic Fingers" \\
\hline & & The alphabet & $\begin{array}{l}\text { The children } \\
\text { mention alphabet } \\
\text { in Indonesia }\end{array}$ & $\begin{array}{l}\text { The children mention } \\
\text { alphabet in English }\end{array}$ \\
\hline & & $\begin{array}{l}\text { The consequence } \\
\text { of the player who } \\
\text { gets lose: }\end{array}$ & $\begin{array}{l}\text { The loser's face } \\
\text { will be drwan } \\
\text { with lipstick or } \\
\text { powder }\end{array}$ & $\begin{array}{l}\text { The player who gets } \\
\text { lose will not get a } \\
\text { point }\end{array}$ \\
\hline \multirow[t]{3}{*}{2.} & Jamuran & $\begin{array}{l}\text { The name of the } \\
\text { game }\end{array}$ & Jamuran & "My Rainbow" \\
\hline & & The songs: & Jamuran & Rainbow song \\
\hline & & $\begin{array}{l}\text { The commands } \\
\text { given by the } \\
\text { victim }\end{array}$ & $\begin{array}{l}\text { Jamur lot kayu } \\
\text { Jamur kethek } \\
\text { menek }\end{array}$ & $\begin{array}{l}\text { To find something } \\
\text { with a particular } \\
\text { colour }\end{array}$ \\
\hline \multirow[t]{2}{*}{3.} & $\begin{array}{l}\text { Oyak } \\
\text { oyokan }\end{array}$ & $\begin{array}{l}\text { The name of the } \\
\text { game: }\end{array}$ & Oyak - oyokan & "Run and Chase" \\
\hline & & $\begin{array}{l}\text { The role of each } \\
\text { chase (someone } \\
\text { who is being } \\
\text { chased) }\end{array}$ & $\begin{array}{l}\text { Each chase must } \\
\text { run to avoid the } \\
\text { chaser. He is over } \\
\text { when the chaser } \\
\text { is able to touch } \\
\text { him. Then, he }\end{array}$ & $\begin{array}{l}\text { Each chase must run } \\
\text { to avoid the chaser. } \\
\text { When the chaser } \\
\text { almost catches him, } \\
\text { he should mention } \\
\text { one part of body and }\end{array}$ \\
\hline
\end{tabular}




\begin{tabular}{|c|c|c|c|c|}
\hline & & & $\begin{array}{l}\text { will be the next } \\
\text { chaser replacing } \\
\text { the previous one }\end{array}$ & $\begin{array}{l}\text { point it. If he is not } \\
\text { able to mention } \\
\text { correctly, he is over } \\
\text { and has to become } \\
\text { the next chaser }\end{array}$ \\
\hline \multirow[t]{4}{*}{4} & Engklek & $\begin{array}{l}\text { The name of the } \\
\text { game: }\end{array}$ & Engklek & "Funny Hop" \\
\hline & & $\begin{array}{l}\text { The formt of the } \\
\text { area to play: }\end{array}$ & $\begin{array}{l}\text { Seven squares are } \\
\text { drawn on the } \\
\text { floor or the } \\
\text { ground. They are } \\
\text { combined } \\
\text { resembling a } \\
\text { cross }\end{array}$ & $\begin{array}{l}\text { Seven square are } \\
\text { drawn on the floor or } \\
\text { on the ground. They } \\
\text { are combined each } \\
\text { other and in row. }\end{array}$ \\
\hline & & $\begin{array}{l}\text { The role of the } \\
\text { player: }\end{array}$ & $\begin{array}{l}\text { The player must } \\
\text { hop the squares } \\
\text { one by one by } \\
\text { using one of his } \\
\text { feet }\end{array}$ & $\begin{array}{l}\text { The player must hop } \\
\text { the squares one by } \\
\text { one using one of his } \\
\text { feet and also mention } \\
\text { the days in English }\end{array}$ \\
\hline & & $\begin{array}{l}\text { The role of the } \\
\text { game: }\end{array}$ & $\begin{array}{l}\text { The player is } \\
\text { over when: } \\
\text { The tile that he } \\
\text { throws falls } \\
\text { outside the } \\
\text { square or lies } \\
\text { exactly on the } \\
\text { line of the square. } \\
\text { He falls of in } \\
\text { hoping the game. } \\
\text { One of his feet }\end{array}$ & $\begin{array}{l}\text { The tile that he } \\
\text { throws falls outside } \\
\text { the square or lies } \\
\text { exactly on the line of } \\
\text { the square. } \\
\text { He falls of in hoping } \\
\text { the game. } \\
\text { One of his feet } \\
\text { touches the line of } \\
\text { the square when he is } \\
\text { playing }\end{array}$ \\
\hline
\end{tabular}




\begin{tabular}{|l|l|l|l|}
\hline & & $\begin{array}{l}\text { touches the line } \\
\text { of the square } \\
\text { when he is } \\
\text { plyaing }\end{array}$ & $\begin{array}{l}\text { Het able to } \\
\text { mention the days } \\
\text { correctly }\end{array}$ \\
\hline The game & $\begin{array}{l}\text { A piece of tile for } \\
\text { each player }\end{array}$ & $\begin{array}{l}\text { A Piece of tile for } \\
\text { each player } \\
\text { Piece of "day paper" }\end{array}$ \\
\hline
\end{tabular}

\section{Games Evaluation}

After modifying the game, the researcher tried out the modified games to small numbers of children. The researchers trying out the games one by one to small numbers of children according to the group each game.

- Magic Fingers (adopted from Sobyong)

Sobyong were tried out to five children. The children play this game easily since the children had already known Sobyong before. The children practiced alphabet. The used was name of their classmate. However, sometimes children were trapped between the sound and spellings, for instance when the last spreading finger the child pointed fell into G, some of the children mentioned "Joko". This name has J as their initial letter although its sound in Indonesia is similar to the sound $\mathrm{G}$ in Indonesia. However, this was good lesson for the children because afterwards they became aware that letters in English sounded differently from letter in Indonesia.

- My Rainbow (adapted from Jamuran)

The children were enthusiastic to play this game. The children mentioned the color of the things they brought and froze immediately before the victim caught them. For example, a child touched a leaf and said " it's green".

- $\quad$ Run and Chase (adapted from Oyak = oyakan)

This game was played by three groups, each of the group consisted 3 children. When trying out, the children could practice the vocabulary part of body. Every child was demanded to think fast what of part body he pointed to avoid the 
chaser's catching.

- Funny Hop (adapted from Engklek)

There are three girls played "Funny Hop". The drew the six squares which were combined in row. They also looked for two pieces of a tile as the instrument part of playing "Funny Hop". They put a stone each of the paper so that the wind could not blow the paper. Then the two children did a lottery. The child who got the first turn threw his tile to the first square. Before she did this turn, her opponent placed a piece of small paper in each of the square. each of the small paper was written a name of day in Indonesia. Then he could hop each square and mentioned the days in English. It was found that sometimes the opponent did not really pay attention that the player did mistake in mentioning the days in English. In this case, there was a child who mentioned Sunday instead of Wednesday for the written word Rabu. The opponent might do not really memorize name of days either.

It can be concluded that the games retrofitted by the researchers were well accepted by children age $6-11$ and able to serve them in learning English vocabulary.

\section{CONCLUSION}

The result showed that Javanese traditional games: Learning alphabet was the result retrofitted from Sobyong game, Learning days was the result retrofitted from Engklek game, Learning Colors was the result retrofitted from "Jamuran" game, and Learning part of body was the result retrofitted from "Oyak- Oyakan". These modification games were able to enjoy the english vocabulary learning process. 


\section{REFERENCE}

Ariani, Christriyati, (1998), Pembinaan Nilai Budaya Melalui Permainan Rakyat Daerah Istimewa Yogyakarta. Yogyakarta: Depdikbud.

Budiyanto, Agus. (1987). Instructional Games: An Enhancing Complementary Method, A Thesis. Yogyakarta: IKIP Sanata Dharma.

Campbel, Linda., and Cambel Bruce. (1996). Multiple Intelligence. Boston: Allyn \& Balcon

Dharmamulya, (2004), Permainan Traditional Jawa, Yogyakarta: Taman Siswa

Ioannidi, et.al., (2016), Designing Games for Children with Development Dissabilities in Ambient Intellegence Environment, International Journal of Child-Computer Intearction,

http://dx.doi.org/10.1016/j.ijcci.2016.10.008

Jui-Ching Wang, (2015), Games Unplugged! Dolanan Anak, Traditional Javanese Children's Singing Games in the 21 st-Century General Music Classrom, National Association for Music Education, Sage Publication,Vol. 28, No. 2, January, 5 - 10.

DOI: $10.1177 / 1048371314551412$. gmt.sagepub.com/

Kemp, J.E. (1977). Instructional Design: A Plan for Unit and Course Development. Belmont: Fearon-Pitman.

Lado, Robert. (1964). Language Teaching Games and Contests. New York: McGraw-Hill, inc.

Malinverni, et.al., (2016), An Inclusive Design Approach for Developing Video Games for Children with Autism Spectrum Disroder, Computer in Human Behavior, Elsevier, 1 -15.

www.elsevier.com/locate/comphumbeh

Taylor, Linda. (1990). Teaching and Learning Vocabulary. New York: Prentice Hall, inc,

Yalden, Janice. (1987). The Communicative Syllabus. London: Prentice Hall International, Ltd. 